\title{
On languages on islands
}

Nash, Joshua; Bakker, Peter; Bøegh, Kristoffer Friis; Daval-Markussen, Aymeric; Haberland, Hartmut; Kedwards, Dale; Ladhams, John; Levisen, Carsten; Markússon, Jón Símon; Robbe, Joost Roger; Willemsen, Jeroen

Published in:

Acta Linguistica Hafniensia: International Journal of Linguistics

DOI:

$10.1080 / 03740463.2020 .1736747$

Publication date:

2020

Document Version

Peer reviewed version

Citation for published version (APA):

Nash, J., Bakker, P., Bøegh, K. F., Daval-Markussen, A., Haberland, H., Kedwards, D., Ladhams, J., Levisen, C., Markússon, J. S., Robbe, J. R., \& Willemsen, J. (2020). On languages on islands. Acta Linguistica

Hafniensia: International Journal of Linguistics , 52(1), 81-116. https://doi.org/10.1080/03740463.2020.1736747

\section{General rights}

Copyright and moral rights for the publications made accessible in the public portal are retained by the authors and/or other copyright owners and it is a condition of accessing publications that users recognise and abide by the legal requirements associated with these rights.

- Users may download and print one copy of any publication from the public portal for the purpose of private study or research.

- You may not further distribute the material or use it for any profit-making activity or commercial gain.

- You may freely distribute the URL identifying the publication in the public portal.

Take down policy

If you believe that this document breaches copyright please contact rucforsk@kb.dk providing details, and we will remove access to the work immediately and investigate your claim. 
Joshua Nash ${ }^{\mathrm{a}, \mathrm{b}}$, Peter Bakkerc, Kristoffer Friis Bøeghc, Aymeric Daval-Markussen ${ }^{c}$, Hartmut Haberland ${ }^{d}$, Dale Kedwards ${ }^{\mathrm{e}, \mathrm{f}}$, John Ladhams ${ }^{\mathrm{g}}$, Carsten Levisen ${ }^{\mathrm{d}}$, Jón Símon Markússon ${ }^{\mathrm{c}, \mathrm{h}}$, Joost Robbe ${ }^{\mathrm{c}}$, and Jeroen Willemsen ${ }^{c}$

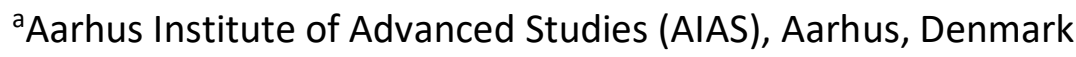

${ }^{b}$ Discipline of Linguistics, University of New England, Armidale, Australia

'School of Communication and Culture - Linguistics, Aarhus University, Aarhus, Denmark

${ }^{\mathrm{d} D e p a r t m e n t}$ of Communication and Arts, Roskilde University, Roskilde, Denmark

eVigdís Finnbogadóttir Institute of Foreign Languages, University of Iceland, Reykjavík, Iceland

fDepartment of History, University of Southern Denmark, Odense, Denmark

gDepartment of Social Anthropology, University of St. Andrews, St. Andrews, Scotland

hFaculty of Icelandic and Comparative Cultural Studies, University of Iceland, Reykjavík, Iceland

\section{Abstract}

Islands as specific research sites in their own right have been given little direct attention by linguists. The physical segregation, distinctness, and isolation of islands from mainland and continental environments may provide scholars of language with distinct and robust sets of singular and combined case studies for examining the role of islandness in any appreciation of language. Whether distinct and particular sociolinguistic and typological phenomena can be attributable to islands and their islandness and vice versa remains unexplored. This position article considers the possibility of there being anything particular and peculiar about languages spoken on islands as compared to languages spoken on mainlands and continents. It arose out of a workshop titled 'Exploring island languages' held at Aarhus University, Denmark on 30 April 2018. The main question posed was: Is there anything special socially, linguistically, grammatically, and typologically about the languages of islands? If so, is it possible to talk about such thing as an island language?

\section{Keywords}

Creoles, frames of spatial reference, island languages, linguistic isolates, sociolinguistics

\section{Contact}

Joshua Nash $₫$ jnash7@une.edu.au $\cong$ School of Humanities, Arts, and Social Sciences, University of New England, Armidale NSW 2351, Australia 


\section{Acknowledgments}

The conceptual foundation for this workshop and position article is based in several probing discussions between Joshua Nash and Peter Bakker in early 2018 about the nature of islands and their cultures, the languages of and on islands, how researchers have done linguistics on islands, and whether or not there is anything special or marked about these languages. The workshop took place at a research island of and on its own, Aarhus Institute of Advanced Studies (AIAS), an island-like refuge set away from the hustle and bustle of metric fixated, modern day academia.

\section{Disclosure statement}

No potential conflict of interest was reported by the authors

\section{Notes on contributors}

Joshua Nash is an islophilic generalist-cum-linguist working on the language of Pitcairn Island. He writes about ethnography, the anthropology of religion, architecture, pilgrimage studies, and language documentation. He has conducted linguistic fieldwork on Pitcairn Island and Norfolk Island, South Pacific, Kangaroo Island, South Australia, and New Zealand; environmental and ethnographic fieldwork in Vrindavan, India; and architectural research in outback Australia. He was Associate Professor at Aarhus Institute of Advanced Studies, Denmark in 2018-2019. He is currently Australian Research Council DECRA postdoctoral fellow at University of New England, Armidale, Australia. Joshua was born on a continent not on an island.

Peter Bakker is senior lecturer at Aarhus University. He works at the intersection of typology, historical linguistics and anthropological linguistics. His main research area is the genesis of new languages, including pidgins, creoles, mixed languages and languages created by twins. He was born in Dordrecht, the oldest city of Holland, and located on an island.

Kristoffer Friis Bøegh is a PhD student at Aarhus University. He has conducted fieldwork in the Virgin Islands and is currently writing his dissertation on Crucian, the English-lexifier creole of Saint Croix.

Aymeric Daval-Markussen is an independent scholar. His research interests include creoles and the creolization process, linguistic typology and historical linguistics, as well as computational approaches for the analysis of linguistic phenomena.

Hartmut Haberland is an emeritus professor of German language and the Sociolinguistics of Globalisation at Roskilde University, Denmark. He has published about the pragmatics of German, Danish, Modern Greek and Japanese.

Dale Kedwards is HM Queen Margrethe II Distinguished Research Fellow at the Vigdís Finnbogadóttir Institute for foreign languages at the University of Iceland, the National Museum of Iceland, and the Museum of National History at Frederiksborg Castle, Denmark, funded by the Carlsberg Foundation. His research focusses on the literature and culture of medieval Iceland, with particular emphasis on the relationships between Latinate and vernacular textual cultures.

John Ladhams is a Research Fellow at the University of St. Andrews, Scotland, having worked at Universities in Portugal, Brazil and England since 1971. His principal area of research is the Creolization of Language, Culture, Society and History. 
Carsten Levisen is a Danish linguist and linguistic anthropologist. He is an associate professor at Roskilde University. His research focuses on cognitive semantics, cultural pragmatics, and postcolonial language studies.

Jón Símon Markússon is a researcher and adjunct lecturer at the University of Iceland. His research seeks to account for changes in the inflectional systems of Icelandic and Faroese, from a usage-based cognitive perspective

Joost Robbe is a research fellow at the Department of Linguistics, Cognitive Science and Semiotics at Aarhus University. He works on historical linguistics, particularly within Dutch and German, and Germanic minority languages.

Jeroen Willemsen is a $\mathrm{PhD}$ candidate at Aarhus University specialising in descriptive and comparative linguistics. His PhD-project included a comprehensive description of the Reta language, for which he conducted extensive fieldwork on the islet of Pulau Pura.

\section{ORCID}

Joshua Nash iD https://orcid.org/0000-0001-8312-5711

Peter Bakker iD https://orcid.org/0000-0002-2072-0430

Hartmut Haberland iD http://orcid.org./0000-0001-6174-9443

John Ladhams iD https://orcid.org/0000-0001-9267-2872

Carsten Levisen iD https://orcid.org/0000-0002-7497-2406

Joost Robbe iD https://orcid.org/0000-0003-1931-4854

Jeroen Willemsen iD https://orcid.org/0000-0002-0332-7151

\section{Do island languages exist?}

Islands as distinct research sites have been given little specific attention by linguists. The physical segregation, distinctness, and isolation of islands from mainland and continental environments may provide scholars of language with distinct and robust sets of singular and combined case studies for examining the role of islandness in any appreciation of language. Writers have argued that mountain languages would have more ejectives (e.g. Catford 1977; Everett 2013), and that desert languages would have fewer vowels (e.g. McConvell 1996; Veth 2000). Zettersten (1969: 138) suggested some possible common properties for island languages, believing them to be more conservative, have special vocabulary 
and display 'pristine' place names. Other scholars have examined the degree to which isolation, island biogeography, and time since first settlement explain variation in language diversity among Pacific islands. Gavin and Sibinda (2012) found there is a correlation between language richness of islands and degree of isolation. In a broader study, Nichols (1992) found that there is an association between genetic and structural diversity on the one hand, and the types of areas groups of languages are spoken in, one factor being the spread of peoples throughout a region. However, whether distinct and particular sociolinguistic and typological phenomena can be attributable to islands and their islandness and vice versa remains virtually unexplored.

The possibility of there being anything specific and peculiar about languages spoken on islands as compared to languages spoken on mainlands and continents was discussed by the authors at a workshop titled 'Exploring island languages' held at Aarhus University, Denmark on 30 April 2018. ${ }^{1}$ Some of the languages discussed are islands with creole and other contact languages, others are islands where there is a colonial settler language, and again others are locations where there is an indigenous language, a newlydeveloped non-creole language, or a genderlect. There is a great diversity of islands, locations, geographies, and linguistic mixing around the world. This variety of locations, geographies and language contact results, was demonstrated and represented by the 11 presenters. The overarching question posed was: Is there anything special socially, linguistically, grammatically, and typologically about the languages of islands? And if so, can we talk about such thing as an island language?

This position article advances thinking in the areas of linguistic typology, language contact studies, language ecology, language and geography, studies of space and language, and island studies. The exploration took place as a round table where participants exchanged information about the islands and the languages on which they have worked in an attempt to find commonalities. While we could list the similarities between languages spoken on islands and in mountain and topography-driven languages, our sample of convenience and our chosen foci are exploratory rather than hypothesis testing. We are especially concerned with raising the novel question and research agenda about how languages spoken on islands can contribute to the possibility of the existence of a distinct typological phenomenon. This work is thus offered as an invitation to scholars working on languages spoken on islands and it intends to stimulate research on linguistic aspects relevant to island studies to advance this thinking (see Acta Linguistica Hafniensia 50(2) for a relevant discussion of spatial language, cognition, and environment).

\footnotetext{
${ }^{1}$ Sébastien Doubinsky and Nicolas Tessier contributed to the discussion but not to the text.
} 


\section{What is an island?}

Several authors have discussed individual islands and languages, e.g. Mühlhäusler (1998), Mühlhäusler \& Stratford (1999), Schreier (2003), and, with regards to islands, language, and toponymy, Nash $(2015,2017)$, but no comparative study has been carried out. The fundamental questions of what constitutes an island is far from clear. If we use the definition that islands are landmasses surrounded by water, we admit that all landmasses are surrounded by water at some point in their geography, and hence all landmasses are eventually islands of some sort. Size does play a role; Australia and Antarctica are islands the size of continents. We postulate the admittedly intuitive and problematic notion that an island community is a community whose members are aware that they live on an island without the help of external maps. We concede that there are groups who claim they live on an island, but that their 'island' is in fact a peninsula or other island-like landmass. This is obviously the result of a perception taken from the ground rather than any map-driven reality (see e.g. Wellfelt $(2016,7-8)$ on the perceived separateness of the Bird's Head peninsula of Alor ${ }^{2}$ from the rest of Alor Island in Indonesia).

We believe languages and cultures born and existing in such situations warrant the use of the term relative insularity. Some islands are smaller, more 'islandy', and island-like than others. The people of Pura Island in Indonesia, for instance, may consider Alor and Timor mainlands, although these are also just islands, albeit larger ones in comparison to Pura. Physical, cultural, and linguistic insularity and closeness are never absolute but relative to concrete or abstract measures.

In a number of languages, the word for island may have other meanings as well, for example, wetlands. The Irish word inis (variant inse) can mean both island and wetlands. The Middle English ilond as well as Old English ēaland and ei (a cognate of Scandinavian ey) communicate this dual sense of both island and wetland. (The "s" in the written form "island" is an insertion based on a false etymology.) Similarly, the

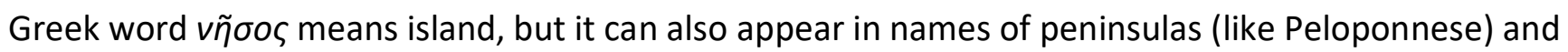
archipelagos (Dodecanese). It also means 'land flooded (by the Nile)' and 'alluvial land' (Liddell and Scott 1940 , s.v. $v \tilde{\eta} \sigma o \varsigma)$. Etymologically, $v \tilde{\eta} \sigma o \varsigma$ is probably related to a verb $v \varepsilon \dot{\varepsilon} \omega$ 'to swim', i.e. where you get by swimming. The Danish word halvø, literally 'half island' and Dutch schiereiland "almost island" for a peninsula is relevant because these suggest that islandness runs along a continuum, or at least, that such a conceptualization of islandness can be reflected in language. Note that what is an island today might well have been a peninsula 1000 or more years ago, or the other way around. Finally, in the Reta language of Pura Island, Indonesia, the word palika can mean both 'island' and 'world' (and also 'land' and 'earth'). Such curious connections between wetlands, peninsulas, and islands seem to be more culturally than geographically driven. For discussion of words for islands in Western European languages, see Ronström (2009).

\footnotetext{
${ }^{2}$ Not to be confused with the better known Bird's Head (Vogelkop) peninsula of West New Guinea.
} 
In several island societies, special terms are in use relating to their own or other islands. For instance, in seventeenth century Island Carib (Breton's dictionary of 1665, Breton 1665), the following terms are given, among others: ámon-chéenti oúbao 'someone from another island', balloüèouri, balloüébonocou 'man from the mainland', balloucaiti, niballoucayénli 'change of island', oubouchoúnacou or lecouchounoucou 'Carib Indian who resides on a neighboring island' and guítênnê, 'head towards another island or the mainland'. Such lexicalizations and compounds are relevant because people identify and name things which are typical for their own island.

Similarly, modern day inhabitants of Vanuatu use a set of compounds with 'island'. In Bislama, the creole language of Vanuatu, there are many terms that relate to customs and objects related to islands, aelan kakae 'local food, in contrast to introduced food', aelan dres 'colourful loose dresses with lace and ribbon trim commonly worn by Vanuatu women, introduced by missionaries in the nineteenth century', aelan bru 'home brew, illegally brewed drink with yeast and fruit' (Crowley 2013, 34-35). Similar terms are also used in the indigenous languages of Vanuatu.

There is an autostereotype about Japan being an island surrounded by water: the term 海外 'kaigai', composed of 'sea' and 'foreign', means both 'overseas' and 'abroad'.

Another fruitful way of exploring the concept of island languages further is to consider a more emic approach. This could involve taking stock of the world's languages and varieties of languages and to see if and how descriptions of these languages pay attention to islands. A minimal and partial definition of an island language from this perspective would be to say that island languages are languages with a word for 'island', which inhabitants use in order to identify themselves. Here we could add that an island language (i) pays attention to islands in its semantic system, including ethnogeographical terminologies, names, metaphors etc., (ii) pays attention to islands in everyday pragmatics of speech acts, including speech acts of identification and speech acts of relationality and (iii) pays attention to islands in its genres and cultural discourses, for example, songs and verbal art.

There are several other considerations as regards island, islandness, peninsulas, and the sea. For example, the aquatic equivalent of a peninsula would be a fjord. However, populations of certain fjords may differ in how they consider themselves the same or different from those groups of other fjords. Further, the concept of what constitutes an archipelago is crucial. Such conglomerations of islands consist of more than three islands, which are connected somehow in terms of culture, language, or administration. In this article, the Faroe Islands, Japan, and Vanuatu are archipelagos rather than islands.

Islands have a number of traits in common such as isolation, conservatism, and a distinct locus of contact. The isolation of islands means often that people that have arrived by water, e.g. beachcombers, are not able to return. Such people can influence these societies and become absorbed into the local societies. Some people who end up on islands might not want to be there. These factors can all influence 
what may constitute an island language. Island-like traits are not unconditional, but are heuristic tendencies. Similarly, when these traits might have an effect on a language or language community, we should think of these in terms of tendencies as well.

\section{The islands considered and their languages}

The islands and archipelagos of which we have knowledge are hugely different from one another. Our sample is one of convenience, with no claim for representativeness. We have taken the following islands or archipelagos into consideration: Amager in and near Copenhagen, Denmark; Annobon in the Atlantic Ocean; the Faroe Islands in the Northern Atlantic Ocean; Haiti in the Caribbean Sea; Iceland close to the Arctic Circle in the Atlantic Ocean; Japan in East Asia; Pitcairn Island in the South Pacific; Reunion Island near Africa in the Indian Ocean; Pura Island in the Indonesian archipelago; Saint Croix in the Caribbean Sea; Saint Vincent and other islands of the Lesser Antilles in the Caribbean Sea, and the Vanuatu archipelago in the South Pacific. These islands and archipelagos are not only spread all over the globe, but the historical, social, and linguistic diversity they represent is vast.

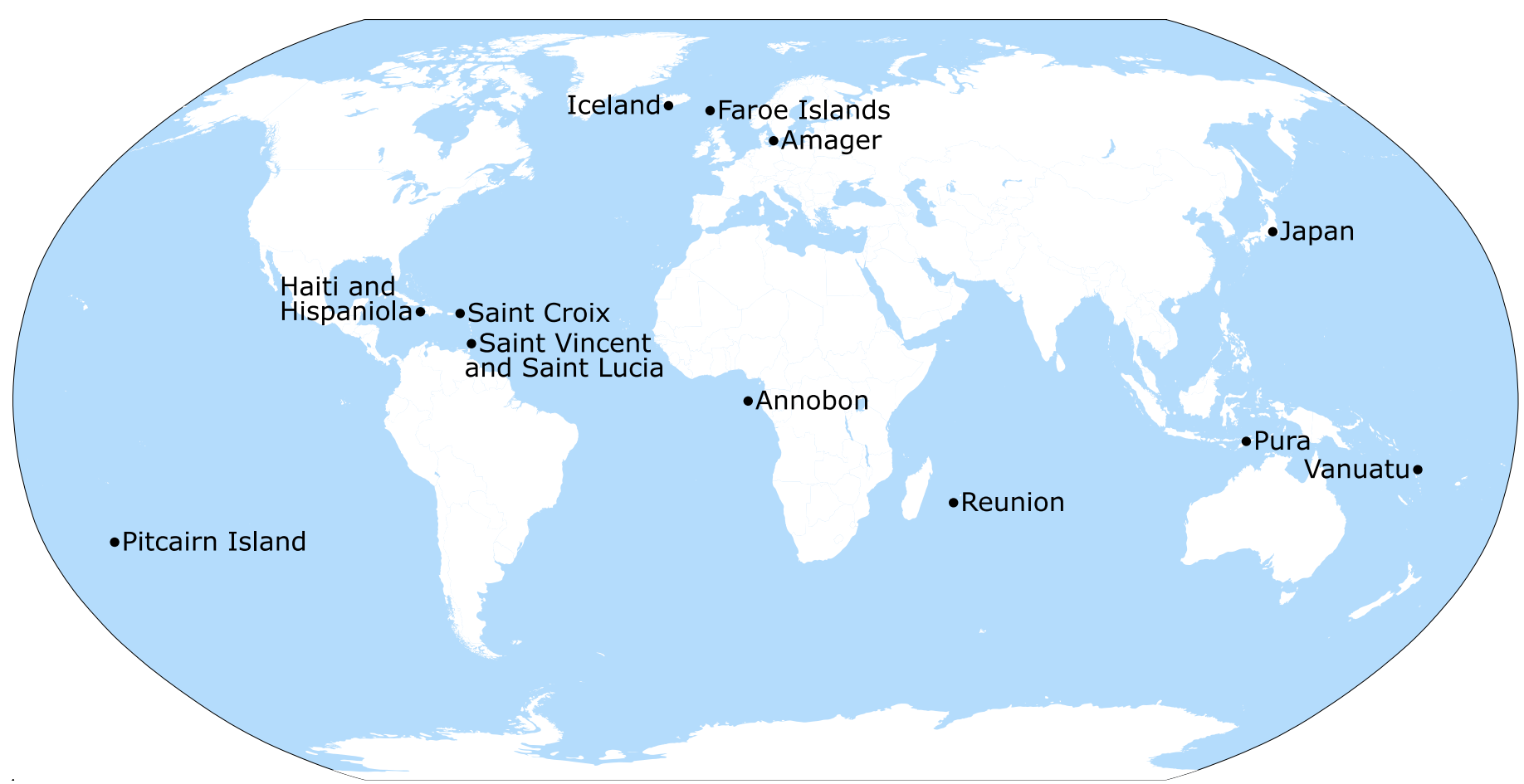

Figure 1: Map with approximate locations of the islands considered in the paper

Pitcairn Island has just over 40 inhabitants whereas Japan has 126 million. An archipelago like Japan is surprisingly homogeneous from a linguistic point of view, despite its size $\left(377,835 \mathrm{~km}^{2}\right.$, or nine times the size of Denmark) and so is Iceland with 340,000 inhabitants. On the other hand, the more modestly-sized Vanuatu archipelago (Lynch and Crowley 2001; François et al. 2015a) boasts the largest number of languages per square kilometer in the world: 138 languages over a geographic area of $12,189 \mathrm{~km}^{2}$, i.e. one 
language per $88 \mathrm{~km}^{2}$ (cf. the size of the Danish island of Funen at 3,000 km² or Manhattan, USA at $59 \mathrm{~km}^{2}$ ). The languages in Vanuatu are also remarkably different from one another (François et al. 2015b). The Papuan language Reta with approximately 2,000 speakers is one of two languages spoken on Pulau Pura in Indonesia $\left(28 \mathrm{~km}^{2}\right)$. Japan has been settled for at least 10,000 years, whereas the Bounty mutineers moved to the then uninhabited Pitcairn Island as recently as 1790 . Other islands were inhabited, and one or more new population groups emerged, after an invasion from elsewhere. The mixed African-Amerindian group of Saint Vincent, with people of African descent identifying as Carib (Garifuna) Indians, and a creole culture and a new language is another example. Saint Croix, the largest of the three present-day US Virgin Islands (formerly the Danish West Indies), was populated by a small group of Europeans and a considerable number of slaves with a previous Amerindian population that soon disappeared through disease, death, and forced migration. During the colonial period, two creole languages were used widely in the Danish West Indies, a Dutch-lexifier creole (dominant in Saint Thomas and Saint John, the northernmost islands of the group), and an English-lexifier creole (dominant in Saint Croix). Annobon was uninhabited when it was settled by less than a handful of Portuguese and 100 enslaved Africans around the 1550s, and they remained almost without contact with the outer world until the beginning of the twentieth century. Réunion was uninhabited until permanently settled by the French and slaves and indentured labourers in the 1660s. As regards the island of Amager, Dutch farmers were invited by the Danish King to settle on the island between 1513 and 1523. The Dutch had their own legislation, schools, and social fabric within the larger Danish population. They preserved their own language, from the beginning influenced by German, until the early 1800s, while all the time interacting with Danish speakers.

Some islands were settled by people who moved there more or less voluntarily (Iceland, Faroe Islands), whereas others were populated by a large majority of involuntary residents in the form of enslaved people (Saint Croix, Saint Vincent, Réunion). On other islands, convicts were among the first to people these islands: Bermuda, in the Caribbean, Mauritius in the Indian Ocean, and Norfolk Island in the Pacific (Maxwell-Stuart 2010; Anderson 2016). Among the first Europeans on Jamaica and Barbados were convicts, as in Australia (not an island). The island of Sainte-Marie, at the mouth of the bay of Antongil in Madagascar ( $\left.16^{\circ} 93^{\prime} \mathrm{S}, 49^{\circ} 83^{\prime} \mathrm{E}\right)$ started out as a prison, as did Les îles du Salut in French Guiana (popularized in the 1973 motion picture Papillon based on Henri Charrière's book).

Distances to associated mainlands, or at least larger land masses, also differ considerably in our islands. Whereas Amager is separated from the much larger island of Zealand by a narrow strait of a few dozen meters, and from Sweden by a strait of some nine kilometers, the island of Annobon $\left(17,5 \mathrm{~km}^{2}\right)$ lies 250 kilometers from the nearest island, and Pitcairn Island lies more than 500 kilometers from the nearest inhabited island. 
At first sight, there is nothing remarkable about the languages of the islands surveyed, except perhaps that all the island communities lean more towards extremities than average languages. Iceland (350,000 inhabitants) is famous for its extreme linguistic conservatism, with relatively few changes during more than a millennium of settlement (Friðriksson 2008), and no dialect differences to speak of today, whereas Saint Croix had successive settlers who were speakers of Arawak, probably also Carib, and certainly Spanish, French, Dutch, Dutch Creole, Danish, Dutch, English Creole, and English (Highfield 2018) within less than a millennium, to mention just the main ones that at some point in time were dominant on the island. Faroese is considered as a linguistic halfway point between Old Norse and the modern mainland Scandinavian languages, having undergone more change than Icelandic, which also descended from Old Norse, but much less change than Danish, Norwegian, and Swedish (see Práinsson et al. 2004).

Amager Dutch clearly reveals the ambiguity of an island language in terms of contact and conservatism. Contact with Danish was unavoidable. On Amager, two communities, one Danish-speaking and one Amager Dutch-speaking, lived side by side, and, in a wider context, Danish was the language of the majority of the country. For two reasons, contact with German was also unavoidable. First, because of its strategic position at the Øresund (The Sound), a busy waterway, Amager has always been in commercial contact with the outside world and thus with (Low) German, which acted as a lingua franca for maritime trading on the North and the Baltic Seas. Second, from the middle of the sixteenth century, after Holland had become Calvinist and Denmark Lutheran, Lutheran priests were invited to Amager from Danish territories in Northern Germany (Hjort 1980: 14). So the use of (Low) German as a lingua franca along with the 'import' of Low German speaking priests may account for the German influences. The Dutch settlers on Amager used their language in church until 1811 and some continued to speak their language until 1858.

Sometimes one language is the only local language spoken on the island (Icelandic), or almost the only one (Japanese), in other cases the islands are multilingual communities of an extreme kind (Reunion, Saint Croix, and Vanuatu). In two cases, the island houses two speech communities, each on their side of the island. Haitian is spoken in Haiti, with a French-speaking minority, and Spanish in the adjacent Dominican Republic, and the tiny island of Pura $\left(28 \mathrm{~km}^{2}\right)$ is home to two indigenous languages, Blagar and Reta, as well as the state language, Indonesian, and its local variety, Alor Malay.

\section{Social history and languages of the islands}

Here we present in alphabetical order brief descriptions of the social history and languages including common sociolinguistic and technical themes of the sample of islands.

Amager: a Dutch island on a Danish, Dutch, and German speaking Danish island 
Amager ( $\left.55^{\circ} 37^{\prime} \mathrm{N}, 12^{\circ} 35^{\prime} \mathrm{E}\right)$ is Denmark's most-densely populated island, with almost 200,000 inhabitants within $96 \mathrm{~km}^{2}$. The island is situated east of Zealand, south of central Copenhagen. Similar to Pitcairn Island, the social history of the island is determined by a single event. The Danish King Christian II (15131523) invited 184 Dutch farmers and their families to live and farm on the island, to whom he awarded certain privileges such as their own government and institutions. However, after Christian II was banned from Denmark in 1523, these privileges were retracted for more than two decades. In 1547, Christian III (1534-1559) officially re-established the rights for the settlers, but only in the southern part of the island (Thurah 1758, 15-17), so all the Dutch settlers relocated to this area. From that time onward, Amager was divided into a northern (Danish) part and a southern (Dutch) part. The Dutch settlers enjoyed a number of privileges, which included their own legislation; they had their own schools and priests. Because of this and a ban on mixed marriages, the Dutch settlers remained a relatively closed community within Denmark.

The language of the Dutch settlers on Amager, referred to as Amager Hollandsk 'Amager Dutch', was characterized as a mixture of Dutch, Low German and Danish by the Danish historian de Thurah (1758, 18). Evidence for a language shift from Holland Dutch to a mixture of Dutch dialects and Low German and Danish can be seen in $17^{\text {th }}$ century texts (Winge 1992; Robbe 2019). Whilst Danish influence remains limited to orthography and lexis, German influence goes further and comprises both phonology and morphology. An example of (Low) German influence on the phonological level is the long e-vowel in Amager Dutch words like deef ('thief'), leef ('dear'), preester ('priest') and deenst ('service') (Robbe 2019). The most striking example of German influence on the morphological level is the reintroduction of a case system into Amager Dutch based on a German model. This case system shows a new dative case with different endings in the three genders in the singular and the plural (Robbe 2019). However, once Amager Dutch was established, it stayed remarkably conservative.

\section{Annobon: a unique microcosm in the Atlantic Ocean with a Portuguese creole}

The island of Annobon (126'S, 5³8' W) (also Annobón, Ano Bom, and, from 1973 to 1979, Pagalu) is located in the Gulf of Guinea off the coast of West Africa. The island is $17.5 \mathrm{~km}^{2}$ with a population of around 5,200. The island was discovered, uninhabited, by the Portuguese, on New Year's Day (Ano Bom > Annobon), probably in the year 1472 . There was no permanent settlement until around the 1550 s, when around 100 African slaves were transported there by the Portuguese, together with one or two overseers. However, it is clear that this initial population was at the very least neglected, if not totally abandoned, by the colonial power, Portugal, for the next $350-400$ years, until the beginning of the $20^{\text {th }}$ century. Annobon, unlike the nearby islands of São Tomé and Príncipe, can be seen as a unique microcosm of total isolation. Not only a creole language developed locally, but also a distinct culture and eventually a 'creole society' (see Caldeira 2009; Wulf 2014a, 2014b). 
Virtually all the 5000 or so inhabitants of Annobon have as their first language Annobon Creole Portuguese (ANN), also known as Fa d'Ambô, which is also spoken by a similar number of Annobonese emigrés in Malabo (Equatorial Guinea's capital), Madrid and Barcelona (Spain). Nowadays, Spanish is the only language used in education and administration on Annobon, while ANN has been ignored, and occasionally suppressed by the Portuguese, since the island was first settled.

While ANN shares a number of features with the other three Gulf of Guinea Creoles - Santomense, Principense and Angolar -, there are only two features in ANN not shared by the other three creoles. This shows that the first influx of slaves on the island in the sixteenth century already consisted of speakers of the Proto-Gulf of Guinea Creole, and that subsequent development of the language on Annobon was minimal, which contradicts the idea that all creolization is gradual (see Ladhams 2009).

\section{Faroe Islands: descendants of Norse settlers who speak insular North Germanic}

The Faroe Islands constitute an archipelago, an almost treeless rocky outcrop, covered by a liberal scattering of grass, in the mid-North Atlantic, situated roughly halfway between Scotland and Iceland. Their total landmass covers roughly $1,400 \mathrm{~km}^{2}$, with the country's population of 50,300 inhabiting 17 of the 18 (main) islands. The country was first settled in the ninth century, mainly by Norsemen often referred to as "Vikings", although the initial waves of settlers were a mix of people from various social strata. The Faroe Islands can be considered an overseas territory of the Kingdom of Denmark from 1814, with Home Rule since 1948. Since 2005, the islands have had full internal self-determination and some degree of external self-government.

The Faroe Islands do not have a law on language, but it is stipulated in the Home Rule Act (1948) that Faroese be recognized as the official language. Danish is a colonial language in the Faroe Islands and the native population considers it a foreign language. They jokingly and affectionately refer to the Danish they speak as Gøtudanskt 'Street Danish' or possibly ‘Danish of the village of Gøta'. However, it is also stipulated that Danish should be learned thoroughly and can be used in public relations (see also Mitchinson 2012).

The Faroese language is, along with Icelandic and the now extinct Norn dialects of Orkney and Shetland, one of the Insular North Germanic languages. Faroese is descended from Old Norse and, particularly, dialects originating in western Norway, eventually carried to the Faroe Islands, Iceland, Orkney and Shetland. There was no significant difference between Faroese, Icelandic, and Norwegian until around 1350. Very few language sources testifying to the historical development of Faroese have survived.

For a language spoken by so few people, Faroese shows considerable dialectal variation from island to island in particular with respect to phonetics (e.g. Karlsson et al. 2012; Weyhe 2014). 
Haiti and Hispaniola: Spanish and French Creole, colonialism and independence

Haiti is not strictly an island but the western half of an island named Hispaniola by the Spanish explorers. The eastern half is another sovereign nation, the Dominican Republic. Columbus landed on the island in December 1492, and the Spanish settled there. Diseases and forced labor soon decimated the indigenous population, from perhaps one million in 1492 to 14,000 in 1517. Hispaniola is today the eleventh mostpopulous island of the world. The French King Louis XIV successfully claimed the western half of the island for France in 1667 and called it Saint Domingue. In the Dominican Republic, Spanish is the dominant language. Since 1667, except between 1822 and 1844, the island consisted of two different administrative districts. When the French took over the western half of the island, they started a society based on the sugar industry with massive slave labor imported from Africa. A successful slave revolt in the late 1700 s led to the independence of Haiti in 1804. The population of Haiti is today close to 11 million, on $27,750 \mathrm{~km}^{2}, \mathrm{a}$ land mass slightly smaller than Belgium. Many Haitians have moved in recent decades to the USA (Florida) and Canada (Province of Québec).

Until 1492, Taino, an Arawakan language, was the main language of Hispaniola and most of the other islands of the Northern Caribbean. Today, Spanish is the sole language of the Dominican Republic, which gained independence from Spain in 1821.

Slaves were brought to Haiti mostly from West Africa and Southwest Africa, and they were speakers of Bantu languages, primarily Kikongo, Yoruba, and Kwa. The population created a new language with the vocabulary of French and an innovative grammatical system with some African influences, called Ayisyen, Kreyòl, or Haitian Creole. The country has two official languages, Haitian and French. The latter dominates the administration and the educational system. Virtually the whole population of Haiti is monolingual in Haitian Creole, 7\% are bilinguals Creole-French (Fattier 2013), and few are monolingual French speakers. Like in most other creoles, tense-mood-aspect is expressed with preverbal particles. Definite and indefinite articles have developed on the basis of French demonstratives and the numeral un/une 'one', respectively, and serial verbs are an African influence in the language (Sylvain 1936; Hall 1953; Fattier 2013).

Iceland: conservative and uniform language spoken by early settlers from Scandinavia and the British Isles

Iceland is located in the North Atlantic, roughly halfway between Canada and Norway. Its closest geographical neighbour is Greenland (350 km). Iceland covers an area of just over $102,000 \mathrm{~km}^{2}$, but boasts a relatively very small population of around 355,000 . Norse settlers reached Iceland in 874 . Early sources also mention that the island was inhabited by a scattering of Irish monks and hermits, referred to as papar, prior to the arrival of Norse settlers. 
Like its sister Faroese (see above), Icelandic is a North Germanic language, descended from the West Norwegian dialects that were carried to the island with the first Norse settlers in the late 9th century. Unlike Faroese, Modern Icelandic still retains active use of the four nominal cases inherited from Old Norse, i.e. nominative, accusative, dative and genitive. Icelandic is generally considered a highly conservative language when compared with its cousins, the mainland Scandinavian languages. Its historical development is also characterised by a greater degree of conservatism than its sister, Faroese (see e.g. Markússon 2017).

A closer connection of Denmark with the Faroe Islands than with Iceland may have contributed to less influence from Danish in Iceland. Many have put its conservatism down to the island's geographical isolation. Guðmundsson (1977) has argued that for centuries the routes which facilitated travel in Iceland mostly were those that followed the coastline, which meant that the different varieties of West Norse spoken among the first settlers were easily carried around the country along a circular route, leading to a gradual neutralisation of dialectal variation.

Japan: a densely populated archipelago and an almost monolingual state Japan covers an area of 377,835 $\mathrm{km}^{2}$ and in 2017 had 126,045,000 inhabitants. Population density is high $\left(337.08 / \mathrm{km}^{2}\right)$, especially considering that many Japanese islands are mountainous and the population is concentrated in a few low-lying basins and along the coast. There is agreement that the Japanese islands were populated in two successive waves, either from the Asian mainland or the Pacific islands, first by the hunter-gatherer Jōmon people and then the farming Yayoi people. There is less agreement about when this happened. We do not know anything about the language of the Jōmon people and little more about the language of the Yayoi. In the course of its history, Japan has both used its proximity to the Asian continent and the fact that it has no land boundaries to choose whether it wanted to entertain close cultural and trade contacts with the outer world or to remain in seclusion. When in the $16^{\text {th }}$ and $17^{\text {th }}$ century European powers (especially the Portuguese) got too interested in contacts with Japan and Christian missions spread over the islands, Japan closed its borders in 1635, prohibiting foreigners to enter the country and Japanese to leave the country.

Japan is one of the most monolingual states in the world, with about $98 \%$ of the population of Japan speaking Japanese. Apart from the close-to-extinct Ainu (an isolate) on the northern island of Hokkaido and speakers of Ryukyu languages in the southernmost parts of the archipelago, which are closely related to Japanese, a few languages of recent immigrants are spoken in Japan, particularly Korean, and Brazilian Portuguese by ethnically Japanese re-migrants from Brazil.

Of all the island languages discussed in this article, Japanese is the only one that has a full Ausbau status, i.e. a fully developed written and spoken standard variety (cf. Kloss 1967 for Abstand and Ausbau 
languages). It is taught both in Japan and abroad and has foreign learners. Emigration to Brazil since 1908 has led to a significant number of ethnic Japanese in Brazil, with a high retention rate of the language, although recent remigration has led to the presence of an ethnic Japanese, Portuguese-speaking group in Japan itself. ${ }^{3}$

Researchers have pointed to the strong structural similarities between Japanese and Korean and also other languages in groupings called Altaic or Transeurasian (e.g. Johanson and Robbeets 2010). While the genetic affiliation of the Japanese-Ryukyu language group is debated, it is clear that Japanese has not only borrowed the writing system from China, and developed it further locally, but also with it a large segment of its vocabulary.

Pitcairn Island: mythical and romantic travellers with a tiny, mystical language Forty-six people live on Pitcairn Island, South Pacific ( $\left.25^{\circ} 04^{\prime} \mathrm{S}, 130^{\circ} 06^{\prime} \mathrm{W}\right)$, a British overseas territory. About two-thirds of these people consider themselves Pitcairn Islanders. The small five-square-kilometer island is famous for its contemporary history derived from a tragic yet notorious maritime event, the mutiny on the Bounty, which took place in 1789 in what is now Tonga. The myth of the island is one of the most famous stories on the planet and the most celebrated in the English-speaking world. The Pitcairn Islanders are per capita likely the most written about people ever to have lived (Young 2016).

There are four islands in the 'Pitcairn Islands' - Pitcairn Island, the only inhabited island, Oeno Island, Henderson Island, and Ducie Island. Located about 500 kilometers south-east of the extreme southeast of French Polynesia, the closest landmass is Mangareva (an island of $15 \mathrm{~km}^{2}$ ) in the Gambier archipelago. Access to Pitcairn Island is by sea and the voyage takes 36 hours from Mangareva. Pitcairn Island is 5,500 kilometers from New Zealand. There is little flatground and the weather may change quickly. Pitcairn Island is one of the most hard-to-reach locations on Earth.

Pitcairn emerged on Pitcairn Island from 1790 in a small community comprised of Polynesian and English speakers. The language developed within a generation as the result of a complex mixing of elements from English, Polynesian, and St Kitts Creole (an English-based Caribbean creole) (Baker and Mühlhäusler 2013). After the move of the entire Pitcairn Island population to the considerably larger Norfolk Island $\left(34 \mathrm{~km}^{2}\right)$ in 1856, several families back-migrated to Pitcairn Island in 1859 and 1864. For almost 150 years, there was little contact between the descendants of these two groups. Around 30 people speak Pitcairn on Pitcairn Island.

\footnotetext{
${ }^{3}$ This is not the only case of speakers of an island language emigrating to another continent, taking the language with them. The Frisian dialects of Föhr and Amrum have speakers in the USA, especially in New York and Petaluma in California (Århammar 2013, 314).
} 
Despite what has been written about Pitcairn - for example, some have claimed it is a prototypical creole (e.g. Sebba 1997) while others have labelled it a patois or any number of language types (e.g. Reinecke et al. 1975) - this variety of English is poorly described and remains ill-understood. The language is on the verge of extinction. The language community has two small diaspora populations in New Zealand and Australia where the language is still spoken by around 60 speakers of differing degrees of fluency.

Pura Island: a volcanic island of Eastern Indonesia where Reta and Blagar are spoken

Pura $\left(8^{\circ} 18^{\prime} \mathrm{S}, 124^{\circ} 20^{\prime} \mathrm{E}\right)$ is a small island consisting of a dead volcano, $1015 \mathrm{~m}$ high, located in between the larger islands of Alor and Pantar in the Nusa Tenggara Timur province of Indonesia. It measures around $6.5 \mathrm{~km}$ from west to east and some $5.5 \mathrm{~km}$ from north to south, and is home to some 6,000 inhabitants and two local Papuan languages, Blagar and Reta (for Blagar see Steinhauer 1991; 1995; 2010; 2014, for Reta see Willemsen 2020). Blagar is spoken in all of Pura Island except one village complex, Pura Selatan, which is the home of Reta. Reta and Blagar are closely related but not mutually intelligible. Little is known about Pura's social history; there are no historical, archaeological or genetic records. It is, however, known that back in the day pillaging and headhunting between tribes were part of the local culture, and that villages were built in inaccessible places high up the mountain, fortified by stone walls and thorny bushes for protection. This resulted in isolation of villages, which in turn fostered independent development of dialects; despite Pura's small size, it houses two languages, and moreover each Blagar village has its own dialect.

Whether Reta and Blagar speakers constituted a homogeneous group arriving on Pura, and why Reta constitutes a separate language from Pura, is not clear. Blagar-speaking villages appear to have been settled originally by a single clan, the other clans being later arrivals (Steinhauer 2010). The same appears to be true for Reta: the main speaker community comprises five clans, only one of which is said to be autochtonous. The non-autochtonous clans come from various parts of the region, and, furthermore, linguistic data shows influences of various languages such as Blagar, Klon and Alorese. All of this points to a complex migration history leading up to the present situation.

Being under serious pressure from Bahasa Indonesia and the local variant of Malay, Reta is threatened. Anything organised on a scale larger than village-level is performed in Indonesian or Malay, which includes church, local, and national media, and school (where the use of local languages is forbidden). Reta is not mutually intelligible with any other language in the area either, so when speakers of Reta and speakers of other languages (e.g. Blagar, Klon) meet, communication is invariably in Indonesian or Malay. Also, with Pura Island offering little opportunity for young people to develop themselves, many of them move away for education and/or work purposes. 
Réunion Island: a French département near Africa, language diversity, and a common creole Réunion Island is a French overseas département (since 1946) located in the south-western Indian Ocean $\left(21^{\circ} 52^{\prime} \mathrm{S}, 55^{\circ} 32^{\prime} \mathrm{W}\right)$. It covers an area of $2,500 \mathrm{~km}^{2}$, roughly the size of Funen in Denmark. It has around 800,000 inhabitants. Although its existence had been known for several centuries, the island remained uninhabited until the 1640s, when a few unsuccessful attempts at settlement were undertaken by the French from a neighboring outpost in southern Madagascar. The first permanent settlement dates to 1665 , when a dozen French settlers accompanied by around 20 Malagasies, disembarked at the island's only natural harbor and took official possession of the territory for the French Crown.

Because Réunion Island is administratively part of France, the official language is French, but a creole language, Réunionnais, has existed on the island since at least the 1720s (Chaudenson 1974, 455). Since the descriptive work initiated by Chaudenson in the 1970s, several book-length studies have been devoted to the creole language of Reunion (e.g. Staudacher-Valliamée 1992; 2004). The use of the creole language is currently on the decline and is slowly being replaced by French, although more than half the population still uses only creole today (Monteil 2010). Apart from French and Réunionnais, a few immigrant languages are also spoken on the island, reflecting the diverse origins of the population. The most important heritage languages spoken today on Reunion are Malagasy (Austronesian, Western Barito), Gujarati (Indo-European, Central Indo-Aryan), Cantonese and Hakka Chinese (Sino-Tibetan, Sinitic), Tamil (Dravidian, Tamil-Malayalam), and Comorian (Niger-Congo, East Bantu). Some of these languages have been spoken on the island from the very early days of settlement (e.g. French and Malagasy), while others were brought successively at later points in time (e.g. Comorian).

Saint Croix: Shifting languages in the Caribbean of Amerindians, Danes, French, Brits, and Africans Located in the Caribbean, Saint Croix is situated east of Puerto Rico and some $60 \mathrm{~km}$ south of the other Virgin Islands. The island's earliest recorded name is Ay-Ay, so named by the Arawak population inhabiting the island prior to European colonization. In 1493, Columbus sighted and named the island Santa Cruz. During the scramble for colonies that followed, the island was claimed successively by several European colonial powers. In 1733, Saint Croix became part of the Danish West Indies, along with Saint Thomas (settled in 1672) and Saint John (1718).

The early colonists on Danish Saint Croix were predominantly English-speaking, as the majority of them came from other British islands in the Leeward group, e.g. Montserrat, Antigua, and Saint Kitts. The economy burgeoned from the 1750s onwards, along with the start of mass importation of enslaved African and Afro-Caribbean laborers. Slave imports came to a halt in the early 1800s (Hall 1992). Slavery was abolished in 1848. A number of waves of in- and out-migration altered the island's demographic make-up over the course of the late nineteenth and especially twentieth century. The 1917 cessation of Saint Croix 
and the other Danish Virgin Islands to the USA resulted in increased cultural ties with the North American mainland. Today, English and an English-based creole - among other languages - are used in Saint Croix.

Historically, many languages have been temporary or long-term parts of the speech community of Saint Croix. American English, the official language since 1917, is widely used in the island. Also widespread is the local Standard English of the Virgin Islands, which is characterized by a number of distinctive phonological and lexical features. It exists in a continuum relation with an English-lexifier creole, locally known as Crucian (or simply 'dialect'), which became entrenched on Saint Croix during the eighteenth century. Creolized English gained ground in Saint Thomas and Saint John as well, but in the nineteenth century. Prior to that, a Dutch creole, which predominated in those islands, also spread to Saint Croix (Sabino 2012; Van Rossem 2017). The Dutch creole never gained status as a lingua franca on Saint Croix, however, unlike on Saint Thomas and Saint John. The last speaker of Dutch creole died in 1987.

Both creoles linked to Saint Croix manifest linguistic features commonly associated with creole languages: They are analytic and SVO, and exhibit a number of semantic distinctions and structural features absent from their lexifiers, e.g. in the verbal domain. Lexically, they display influences from suband superstratal sources as diverse as Kikongo and Danish (Bakker 2004; Bøegh 2018), reflective of their composite developmental histories.

Saint Vincent and Saint Lucia: Amerindians, enslaved Africans and Europeans, a mixed language, a Black Amerindian language, genderlect, and creoles

Saint Vincent (Prescod and Fraser 2008; Prescod 2015) and Saint Lucia (St-Hilaire 2011; Harmsen et al. 2014) are two neighbouring islands of the so-called Lesser Antilles, not far from Trinidad in the Southern Caribbean. Both islands were inhabited by Arawak-speaking Amerindians until around 1300, after which, according to oral history, the islands were invaded by Carib warriors who got rid of the Arawak males. A new language developed which was a variety of Arawak with much Carib lexicon. Shipwrecked and abducted Africans joined them on Saint Vincent from the 1600s, who adopted the language and took it to Central America, where it survives as Garifuna. Europeans and enslaved Africans settled on Saint Lucia from the 1630s. Saint Vincent remained under control of Amerindians until the late 1700s, with their culturally and linguistically assimilated Africans, whereas Saint Lucia shifted between French and British ownership, with marginalized Amerindians.

Today, an English creole dominates Saint Vincent (Prescod 2004), and a French Creole (Carrington 1984) and English are widely used on Saint Lucia. Saint Lucia Creole is very close to the French creoles of the Lesser Antilles (Le Dû and Brun-Trigaud 2011; 2013) and Venezuela. The historical situation is unusual. On Saint Vincent and some other islands of the Lesser Antilles, the Amerindian descendants from Carib males and Arawak females developed a mixed language, with an Arawak grammatical system and mostly 
Carib lexicon (Hoff 1994), but a version of Arawak was also continued. The variety of Arawak was documented in the 1600 s by especially Raymond Breton on the island of Dominica (e.g. Breton 1665). The earliest Black population of Saint Vincent shifted to the local Amerindian language, which survives as Garifuna in Central America (e.g. Haurholm-Larsen 2016; Quesada 2017), but it died out on the islands in the early twentieth century. Garifuna has pronouns and a few lexemes indexical of the gender of the speaker - a rare phenomenon worldwide (Rose 2015). In addition, a special type of French developed, with many Amerindian loans, which was called Le langage des îles (Jansen 2012; Bollée 2015). Furthermore, fragments of Pidgin French have been documented from the 1600s (Bakker, ms.).

\section{Vanuatu: an ex-colonial archipelago in the Pacific with many languages}

Vanuatu is an archipelago, consisting of 83 islands, of which 63 are inhabited. It is a postcolonial island nation in the South Pacific. The country gained independence in 1980 from Anglo-French rule, a colonial condominium until then called New Hebrides and Nouvelles-Hébrides. The South Pacific islands were first inhabited by Austronesians more than 3000 years ago, and later some of the islands were also inhabited by Polynesians. In colonial times, Spanish, French and English explorers were visiting the islands. Sandalwood and bêche-de-mer (sea cucumber) were the two main commodities for the European traders.

In contemporary Vanuatu, the main social groups, according to local classification are blakman, waetman, and jaenaman (or ol sinua). Socio-culturally, the majority of the population forms, with Fijians, Solomon Islanders, Papua New Guineans, and West Papuans, part of 'The Black Pacific'. The waetman group consists of local expats, and a high number of tourists from Australia and New Zealand. There is a considerable Chinese population (jaenaman) in urban areas.

The capital Port Vila is located on the island of Efate. The historically-dominant paradigm of thinking about distance and geography is one of 'archipelagic thinking', where water means connection and possibility, more than boundedness and barrier.

Vanuatu is one of the most language-rich countries in world. François et al. $(2015 \mathrm{a}, 1)$ estimate as many as 138 vernacular languages. In interethnic interactions, as well as in urban areas, Bislama, an English-lexifier creole, is the main means of communication. Bislama is spoken in a variety of ways. The two most important differences are Anglophone and Francophone kinds of Bislama, and rural and urban types. In Vanuatu, schools are either English or French, and people self-identify strongly as mi skul inglis 'I (went to) English school', or mi skul franis 'I (went to) French school'. The Bislama spoken in Francophone schools and other French-based institution and circles, has slightly more French lexis than the Anglophone variety. The urban types of Bislama are characterized by expansion, innovation, and also a considerable anglicization (or debasilectalization). 
In Bislama, both the semantics and the pragmatics are highly attuned to a world in which aelan 'island' plays a crucial role. Bislama pays attention to aelan in ethnogeographical terminologies, naming practices, metaphors etc., and as well as in speech acts of identification and speech acts of relationality. For instance, a person might self-identify in this way: mi Malekula-Ambae 'I'm Malekula-Ambae', mentioning both paternal and maternal aelan 'home island' of his or her parents or ancestors. The question might be a response to the question yu blo wea? 'where are you from', where the conventional implicature could be spelled out as: which aelan are your ancestors from.

\section{Geography and island languages}

In this and the following sections, we will provide a theoretical development and exposition relating the brief historical and sociolinguistic descriptions of the islands to the possibility of island languages.

In recent years, an increasing number of studies have pointed out a correlation between geographical features and linguistic structures. In earlier linguistic work, people had associated the presence of aspirated consonants in alpine dialects of German with the fact that these people would go up and down the mountains, thus transferring their breathing to the consonants (cf. Behaghel 1911, 234), or that Inuit dialects would have uvular consonants, pronounced in the back of the mouth, for they would avoid opening their mouth because of the cold. These claims may sound outrageous now, and they were based on impressions observed in a very small number of languages, but recently such claims have made a comeback.

For example, Everett $(2013 ; 2017)$ and Everett et al. $(2015 ; 2016)$ discussed the observed tendencies that humans in cold and dry areas tend not to develop tone languages, that languages in drier climates have fewer vowels than languages spoken elsewhere, and languages spoken at higher altitudes in mountainous regions use more ejectives. Such studies are usually backed up by statistics, but still there is a risk of finding spurious correlations (Roberts and Winters 2013). Also elsewhere, it has been observed that large numbers of second language learners have a simplifying effect on languages, while isolation and low numbers of speakers favour complexity (McWhorter 2007; Lupyan and Dale 2010; Trudgill 2004, against this Pericliev 2004).

As some islands may be geographically isolated, or have a modest numbers of speakers due to the size of the islands, being spoken on an island may play a special role in the development of languages. In the next section, we discuss island geography and its potential influence on grammar.

Given the geographically and ecologically special case of islands, an island-factor is likely in sociolinguistic typology. But it seems that the 'island affordances', i.e. what an island environment offers an individual or a group, have shifted radically in many cases. In order to refine the etic typology, we need sharper tools. It could be useful to make distinctions in sociolinguistic typology that deal with 'central islands' versus 'peripheral islands' and the shifting nature of this distinction. It is important to define 
precisely what 'island' means in the expert discourse - size is the most obvious parameter (cf. e.g. the island-continent continuum) but relative physical remoteness, and historical geopolitical centrality might be other parameters that could be used to pursue the etic search for island languages.

Alternatively, one could rather than for expert, etic concepts look for participant, emic concepts (which could be called ethnogeographical concepts). One objection to this emic approach could be that 'mountain languages', 'forest languages' or 'lake languages' and other possible linguistic categorisations could be equally viable. Our stance is that there could probably be linguistic universes based on other ethnogeographically salient concepts. Emic terms are not mutually exclusive, and a language could be both an 'island language' and a 'lake language' at the same time. This is not a problem for the concept of island language, rather it is simply a recognition that island ethnogeography is not the only salient ethnogeography in any idea of what a natural language may be.

An additional objection could be that there might not be one shared 'island' concept across speakers of what we have tentatively labelled 'island languages'. This is a major challenge to the emic view, and there would be no way to make any hard emic claims. It would therefore be a priority to do a crosssemantic survey of island-like concepts across those of the world's languages that have words for 'places with water on all or almost all sides'.

\subsection{Grammaticalization of topography on islands: Island orientation systems}

Research into orientation systems and frames of reference has been in vogue in linguistics and anthropology for some time (e.g. Levinson 2003). Frames of reference refer to ways people indicate space. These frames of reference can roughly be divided into the following distinctions: from the speaker's perspective (left, right); from the object's perspective (front, side, back), from a geographical landmark like a volcano, river or sea (towards/away from the mountain, up/downriver, seawards) or absolute (north, south, east, west).

Such geographical orientation systems seem to be most typical for riverine people, mountain dwellers, and islanders. For islands, and especially small islands, establishing a geographical perspective is of paramount importance. However, as far as we know, there are no statistical data with regards to correlations. Heine had calculated that 'landmarks account for less than one-tenth (9.2\%) of all sources for cardinal directions' (1997: 50) in a study of 127 languages. Austronesian languages often have them (François 2004; Ozanne-Rivierre 1997) and these are often spoken on islands. Here we only provide a few case studies as a suggestion for a more systematic investigation.

Islands may lexicalize and grammaticalize the prevailing directions of the wind (windward-leeward, upwind-downwind), or orientation towards or away from the coast or movement parallel with the coast 
line. These can be expressed in, for instance, case systems, verbal derivation or deictic systems. Upfjord and downfjord in Icelandic may be seen as variations of these. Orientation on the basis of the prevailing winds seems to be less common, and often connected to the cardinal directions as well. The Antilles are conventionally divided into leeward and windward groups. For more discussion on landscape and grammar, see Palmer et al. (2017) and the papers in Senft ed. (1997), Burenhult ed. (2008), de Busser and LaPolla eds. (2015), and Boeg Thomsen and Heegård eds. (2018).

Regarding language contact and frames of spatial reference, Pitcairn Island offers the possibility that the linguistic dimension in general may well be an overlay of differing cognitive and spatial models, with a vertical axis (higher/lower) interacting with absolute (north/south) and landmark (seaward/landward) axes. Assessing the development and role of language mixing and cultural contact is key to understanding cognitive spatiality in confined situations like islands (Nash 2016).

In an early study, Heine $(1997,51)$ recognized the importance of islands: "Deictic orientation in terms of the landmark distinction 'toward the sea' versus 'away from the sea' is likely to be prominent in societies that inhabit smaller islands." Bill Palmer has pointed out in several publications that atolls, due to their special shape may have led to special spatial systems in their languages (Palmer 2007; Palmer et al. 2017). Atolls are narrow strips of land surrounding an inner lagoon. Marshallese (Micronesia), Kiribati (Micronesia), Tokelauan (Tokelau) and laai (New Caledonia) all share a deictic system with terms for oceanward, lagoonward and (except Kiribati) wildernessward. Even though all these languages belong to the Oceanic sub-group of Austronesian, they are sufficiently distant geographically to assume that the systems developed independently. The terms used for the directions do not seem to be cognates. Reta too has terms that use the sea and the mountain top as anchors, along with a complex system of grammaticalised markers of deixis, distance and elevation. The Dhivehi language, an Indic Indo-European language spoken on the Maldives, an islands state consisting of 28 atolls, has not developed such a system, despite more than a millennium of residence on the atolls.

Round islands may be home to a different system, where landward/seaward interact with a path along the coast. Palmer $(2015,189)$ illustrates this with the directional system as used on the island of Manam in the Bismarck Sea, worth quoting in full here:

The language has two lexified axes that operate in absolute FoR [Frame of Reference]. One is a landward-seaward axis that crosses the land-sea boundary at right angles. Movement from the interior of the island towards the coast, across the land-sea boundary, and away from the shore at sea is expressed as oro; the opposite direction is oti. This axis is crossed by an axis that runs parallel to the coast, either in the interior, on the coast itself, or at sea. Movement in each direction on this axis is expressed as ra?e [clockwise] or bala [counterclockwise]. Systems such as this are typical for island-based languages (see e.g. Palmer 2002; François 2004). 
This is pervasive in this language and expressed in demonstratives, nouns, verbs and verbal suffixes. A similar system is found in the Taba language of the round island of Makian, South Halmahera, Indonesia, and possibly in Siar (Papuan), spoken on Cape St. George peninsula of New Ireland, Papua New Guinea (Frowein 2017). The coastal language West Greenlandic (Fortescue 1988, 2018) seems to have both as well.

Further orientation systems of island languages (seaward/landward) have been reported for among others Manus (Mead 1956, 57), Kokota (Palmer 2002; 2009), Manam, Makian Taba, Makassarese, Tobelorese on Halmahera Island, Lavukaleve, Balinese (Wassmann and Dasen 1998), Icelandic, Faroese, and Haida on the Queen Charlotte Islands, off British Columbia's west coast (Fortescue 2011, 39-43). Thus, grammaticalization of seaward/landward is clearly not limited to Austronesian languages.

Fortescue $(2018,169)$ also makes another observation that has to do with the possibility of travel on the Island. On the Queen Charlotte Islands travel along the coast on land was very difficult due to dense forestation, but it was possible in Iceland and Greenland, and therefore "local 'along coast' terms equivalent to those of both Icelandic and Greenlandic are lacking" in Haida spoken on the Queen Charlotte Islands. This may also be the case for Boumaa Fijian of Taveuni Island (see Frowein 2015, 257-258). In addition, Fortescue's observations have implications for differences in systems depending on the size of the islands (Fortescue 2018, 176), distinguishing small scale (immediate visual field), medium scale (home base within a day's travel) and large ones (country or known world). Malagasy on the island of Madagascar also has an elaborate deictic system based on a visible vs. non-visible distinction (Rajemisa-Raolison 1966).

Terms of direction in Old Norse-Icelandic derive from Iceland's insular nature and the specific topography of the Norwegian coastline. The direction of travel to Iceland from Norway or the British Isles was usually described as út (out) rather than simply vestan (to the west). Also, the system of spatial orientation seems to have developed around the orientation of the western coast of Norway. As Tatjana Jackson puts it, Icelanders used "not only the names of the four cardinal directions (norđr, austr, suđr, vestr), but also the names of the intermediate ones, those that reflected the peculiarities of the western coast of Norway. Thus, landnorđr, 'north by the land' meant northeast, útnorđr, 'north and out, away' meant northwest; correspondingly landsuðr meant southeast, and útsuðr southwest" (Jackson 1998, 73).

In short, island orientation systems suggest several deictic and orientational systems typical for island and coastal languages. Such systems, however, do not seem to have developed in newly-populated islands in archipelagos like the Caribbean and the Indian Ocean. There are two overarching findings here. First, orientation systems interact with the shape of islands. There is also a greater need for speakers to orientate themselves near a coast. Second, population history matters for the development of orientation systems. Potentially rapid population replacement, the influx of new populations, and the role of linguistic conservatism of islands affect the development of spatial orientation systems on islands. 


\subsection{Islands and linguistic isolates: almost no isolates on islands}

According to the most recent count (Glottolog, Hammarström et al. 2018) there are 188 language isolates in the world. We define a language isolate as a language with no known or proven relatives, except for dialectal variation (which may be considerable). Language isolates can be the only remnants of erstwhile language families, or languages that have diverged so much from its relatives that a historical connection can no longer be established. Both contact resulting in shift and isolation may thus be responsible for the emergence of isolates, but probably always at considerable time depth.

Even though one could think that islands are ideal for the development of single language families due to lack of contact, this appears not to be the case. In Nichols' (1992) terms, insular regions may not be typical residual zones. On the contrary, isolates appear only in very rare cases to be spoken on islands (see below for examples). Even a cursory look at all the world's isolates (e.g. Muzurkiña 2019) demonstrates that most of them are not spoken on islands, but rather in mountainous areas.

There are indeed isolates on continents like Australia and very large islands like New Guinea, but hardly any on smaller islands. There is likely an increased chance of some degree of isolation in an island community. This can be represented in, for example, relative complexity (e.g. some of the languages of Vanuatu) and conservativism (e.g. Iceland). We must bear in mind, however, that a body of water can separate a community from others, but water can also be a means of transport connecting communities. Mountain communities are often much more isolated than islands.

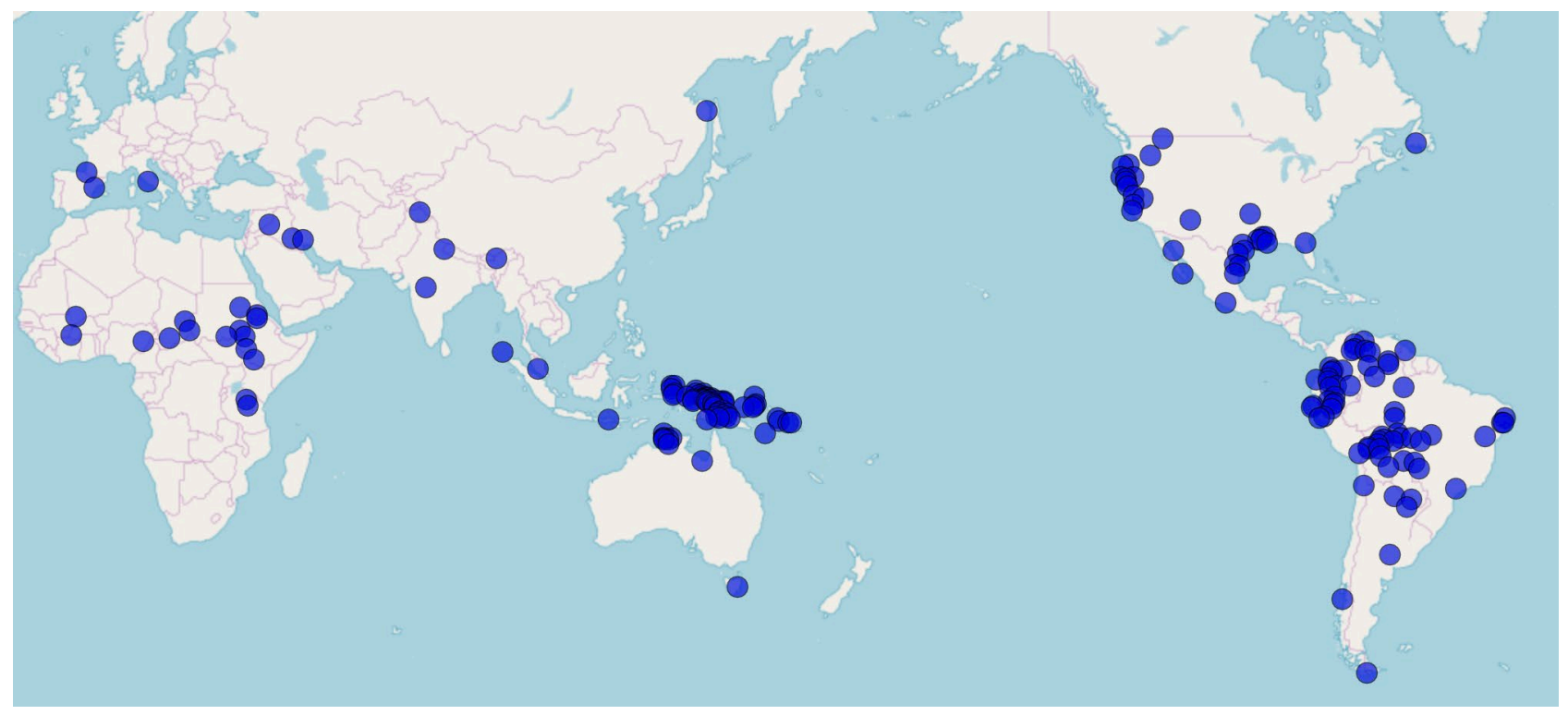

Figure 2: Map with the 188 known linguistic isolates of the world 
Figure 2 shows the 188 both extant and extinct language isolates as identified in Glottolog. ${ }^{4}$

It is striking that all of the African isolates are interior languages. In Eurasia, only Nivkh (spoken on the Eurasian mainland and the coast of the island of Sakhalin) and Basque are coastal languages. There are 50 isolates in the area of New Guinea and surrounding islands, and only around a dozen of them are spoken in coastal areas. Similarly, in South America only a handful of the approximately 80 isolates are coastal languages.

If we limit ourselves to isolates spoken as the (almost) only language on an island, there are only a handful in the world: Shom Peng, spoken on Great Nicobar Island in the Indian union territory of the Andaman and Nicobar Islands; Yele, spoken on the easternmost island of the Louisiade Archipelago off the eastern tip of Papua New Guinea; Savosavo, an endangered language spoken on Savo, a small volcanic island north of Guadalcanal in the Solomon Islands; Lavukaleve (spoken on the island of Pavuvu, Solomon Islands), Tiwi, an Australian Aboriginal language spoken by the Tiwi people on the Tiwi Islands; Bilua, is a Central Solomon language spoken by about 9,000 people on the island of Vella Lavella; Touo, spoken over the southern part of Rendova Island in the Western Province of the Solomon Islands. Haida and Ainu, although not represented on the map, may be seen as isolates spoken on islands off the coast of Alaska and British Columbia, and the Japanese island of Hokkaido, respectively. ${ }^{5}$ Haida, Nivkh and Ainu are not the only languages spoken on the islands where they are spoken, or not spoken only on those islands. This is a remarkably low number, covering only around $2-4 \%$ of the world's language isolates. An explanation may be that the languages of islands (and coastal areas) are replaced through invasions more frequently than languages of the interior, especially when these are spoken in remote mountainous areas. The fact that contact languages and new languages like creoles tend to be found on islands is a consequence of more frequent language replacement on islands.

\subsection{Islands and contact languages}

Contact languages are new languages, which develop through contact involving several languages and often more than one culture. Language isolates appear underrepresented on islands, whereas contact languages appear to be overrepresented on islands. Taylor (1971) compared 13 creoles, seven of which are spoken on islands, while the others are located in the vicinity of the coast. Hancock (1987) contains data on

\footnotetext{
${ }^{4}$ We thank Harald Hammarström for his help. The map was generated as follows: https://glottolog.org/glottolog/language.map.html?type=families\&sEcho=1\&iSortingCols=2\&iSortCol_0=4 \&sSortDir_0=desc\&iSortCol_1=0\&sSortDir_1=asc\&sSearch_1=Isolate\#2/-2.3/159.2 ${ }^{5}$ Hammarström et al. 2018 do not count these languages as isolates because they consider them as clusters of closely related 'languoids' (describable units, which also could be dialects). But when closely related languoids spoken in a coherent area do not have any relatives otherwise, one could reasonably count the language made up by them as an isolate as well. This means that North and South Haida are not isolates (because cognate with each other) but Haida still is.
} 
33 restructured varieties of English, 18 of which are spoken on islands, and all but one not far from the coast.

The atlas of contact languages APiCS (Michaelis et al. 2013) contains data on 76 languages. A rough count shows that 32 of the 76 contact varieties are spoken on islands, a few more on peninsulas and most developed in coastal regions. In the overview of 18 creole languages in Holm and Patrick (2007), 11 are spoken on islands. Of the 17 languages dealt with in Schreier et al.'s (2010) The Lesser-Known Varieties of English, 12 are spoken on islands and all others either on peninsulas or in coastal areas. Nine of the 13 languages considered in Further Studies in the Lesser-Known Varieties of English (Williams et al. 2015) are spoken on islands. Clearly, islands boast many more contact languages than landmasses, and almost all of those not spoken on islands are associated with coastal regions.

Thus, islands are overrepresented as habitats among the contact languages of the world, and underrepresented as homes for isolates. This would mean that islands are contact zones rather than 'isolated' locations. In the Philippines, an archipelago, as can be seen on language maps (see Figure 3), relatively many islands host several languages, while a single language can sometimes be spoken on adjacent coastal areas of different islands. This is also true for Reta and Blagar in Indonesia. Blagar is spoken on the same island as Reta, but also on a large part of the east coast of the adjacent island of Pantar, and Reta is also spoken in southern Ternate ${ }^{6}$ and in two small settlements on the west coast of Alor. Such observations also suggest that the bodies of water separating the islands were highways of aquatic traffic, rather than boundaries and barriers (cf. Marck 1986).

${ }^{6}$ Not to be confused with the island of the same name in the Moluccas, after which it was in fact named. 


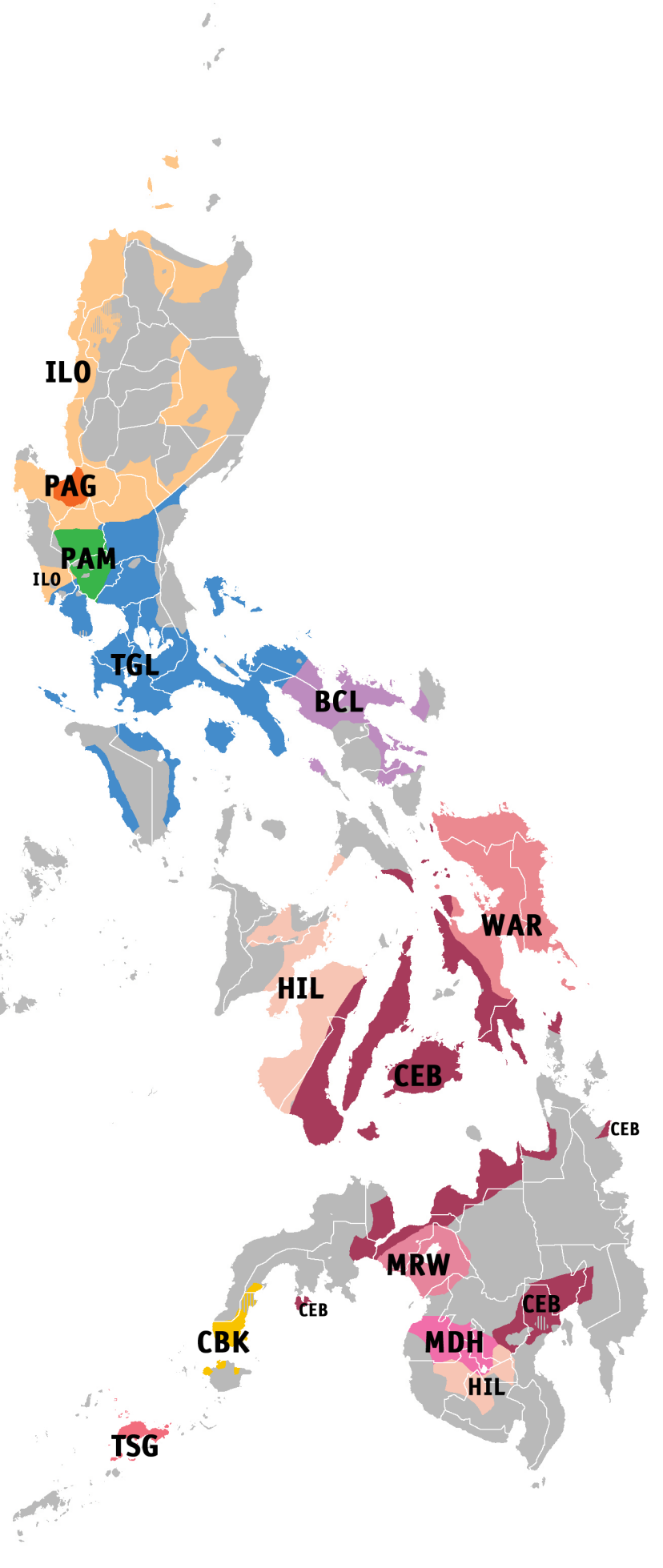

Figure 3: Major languages of the Philippines. Many languages like Cebuano (CEB), Hiligaynon (HIL), Tagalog (TGL), are spoken on opposite coasts of bodies of water. (Map by Roel Balingit based on data from Ethnologue, Eberhard et al. 2019).

On the other hand, islands can be very conservative in their developments. Thus, Iceland is known for its linguistic conservatism, having preserved a language that has undergone relatively few changes in the last 
1000 years. It has recently been highlighted that there was a sizeable Irish speaking population in early Iceland, who must have somehow shifted from Irish to Icelandic without leaving many traces in the language (see also Pálsson 1996). Most of the Irish may have been thralls, and hence less likely to exert linguistic influence. Faeroese had a similar settlement history, but it underwent fairly radical changes in the phonology and verbal and nominal morphology. Its stronger connection to Denmark is most likely the reason for this.

As political units, islands have been claimed (Anckar 2002) to have been more stable and more democratic, in spite of obvious counterexamples. The relatively stronger democratic tendencies may be because they have clearly demarcated geographical borders. State borders such as those between Finland and Russia or between Germany and France borders have been constantly changing through time. Could this apply to the languages of islands as well? The language border between Faroese and Icelandic is certainly more clear-cut than that between Norwegian and Swedish, or between Danish and German. The relationship between Korean and Japanese (spoken in two neighboring countries divided by a clear border on a body of water) is special in that the languages share many more grammatical properties than lexical material.

\section{Conclusions}

Why have researchers researched island languages and why do they continue to do so? For some researchers, it is appealing from a common-sense perspective: islands are often socially and geographically isolated, the cultural traditions that thrive on such islands are often somehow unique due to the relative isolation of the community, and researchers make the logical leap that this uniqueness could also characterize the island community's speech.

Languages spoken in mountainous areas have been claimed to have special features. But why has nothing been claimed for islands? Zettersten's proposed universals of island languages (1969) refer to archaisms in lexicon and structure and innovation in toponymy, i.e. shared patterns of change, but he did not search for shared features. Neither have we discussed specifically which grammatical features are may constitute what might be termed a prototypical island language. However, we have suggested that there are several intriguing links involving the social history of certain islands, orientation systems, language and isolation, language contact, linguistic isolates, and some hints of how island geographies affect grammar.

Paradoxically, islands seem to be contact zones with exceptional degrees of fluctuation as well as conservatism. The most conservative Germanic varieties are spoken on the island Iceland, but also in a valley in the middle of the Swedish mainland (Elvdalian or Dalecarlian, Dahl 2005), and Faroese changed as rapidly as mainland Danish.

Strikingly, less than a handful of islands are home to language isolates, which also suggests that islands are contact zones rather than isolated from the rest of the world. Populations may be more easily 
replaced or merged in islands. The fact that there are so few language isolates on islands could be because of size and population restraints. Numerically or militarily advantaged populations reaching an island may replace the original population because there are fewer easy escape possibilities as compared to terrestrial situations. In other locations populations can flee to mountains, deserts, or to other less accessible environments. They are more able to preserve their language. Thus, the replacement rate is higher on islands than elsewhere.

Travel by water was much more common in the past than it is today (cf. the famous study of the Brunlanes peninsula in Norway by Trudgill 1974). One has to disentangle the geographical and modern metaphorical resonances of the terms 'insular' and 'isolated'. A definition of an island as a site of physical removal and segregation might be difficult to substantiate. We have seen that language isolates are rarely spoken on islands; on the contrary, many islands appear to be contact zones. In the case of Iceland also, the island is connected to, not separated from, other places by water; human habitation is mostly coastal, and travel by boat may be easier than travel across the inhospitable interior.

Recent work in literary studies has emphasised transmarine connectivities across the North Seathe sea being that which connects, rather than divides, the British Isles and Ireland. Rouse (2016), for example, summarises the case for 'the fiction of maritime British insularity'. If British insularity is a myth, this can be extended to the North Atlantic, where we can notice that the geopolitical units where varieties of Old Norse were used like Iceland, the Faroe Islands, the Shetland and Orkney Islands always had relative insularity. Places like Iceland have certainly been more isolated (and one can think, from whom or what?) in some historical moments than others. As insularity is socially produced as well as reflecting some kind of geographical situation, it is worth realizing that degrees of insularity are to a large extent historically contingent.

The Austronesian migrations, first from Taiwan, and then through much of the Philippines, Melanesia, and Oceania, were probably partly triggered by lack of space (Bellwood 2017). This also showcases how waterways really were highways and in no way hindered the movement of populations. In the case of the Austronesian languages, the linguistic outcome of the disappearing phonemes is compelling: the further east the Oceanic languages are spoken, the fewer consonants are found in the languages (Trudgill 2004).

Finally, we should mention the language spoken on North Sentinel Island, probably the blankest spot on the map of the world's languages. We do not know anything about the language (not even if it is only one), and it remains unclassified. Sentinelese might represent the ultimate conceptualization of an isolated island language. The population must have come from elsewhere, at some point in time, by water. Perhaps Sentinelese will eventually show that islandness can be a characteristic of a language if it is not influenced by other kinds of languages, shaped according to specific geographical and topological 
conditions that constitute a part of their speakers' everyday reality and possibly even influence their cognitive relation to the environment.

In closing, we offer this position paper as a basis of further thinking about the nature of the interaction between languages and their incident environments, with implications for linguistic typology (in our case grammar), social typology (people history), language contact and the study of isolates. We hope that these case studies, presentations of data, and arguments have muddied the theoretical water enough to stimulate more thinking regarding the character of languages spoken on islands and how relative geographical isolation might have an impact on language.

\section{References}

Anckar, Dag. 2002. "Why are small island states democracies?" The Round Table 365: 375-390.

Anderson, Clare. 2016. "Transnational Histories of Penal Transportation: Punishment, Labour and Governance in the British Imperial World, 1788-1939." Australian Historical Studies 47(3): 381-397, DOI: 10.1080/1031461X.2016.1203962.

Århammar, Niels 2013. „Das Friesische im Sprachkontakt.“ In: Handbuch des Friesischen/Handbook of Frisian Studies, edited by Horst Haider Munske et al., 313-353. Berlin: de Gruyter.

Baker, Philip and Peter Mühlhäusler. 2013. The creole legacy of a bounteous mutineer: Edward Young's Caribbean contribution to the language of Pitcairn and Norfolk Islands. Acta Linguistica Hafniensia 45(2): 170-186. DOI: 10.1080/03740463.2014.897814.

Bakker, Peter. 2004. "Låneord fra dansk i vestafrikanske og vestindiske sprog." Mål og Mæle 27(3): 28-32.

Bakker, Peter. manuscript. Evidence for pidgins evolving into creoles in the French Caribbean.

Bakker, Peter and Maarten Mous, eds. 1994. Mixed Languages. 15 Case Studies in Language Intertwining. Amsterdam: IFOTT.

Barassin, Jean. 1953. Bourbon des origines jusqu'en 1714: naissance d'une chrétienté. Saint-Denis: Imprimerie Cazal.

Behaghel, Otto. 1911. Geschichte der deutschen Sprache. Straßburg: Trübner.

Bellwood, Peter. 2017. First Islanders: Prehistory and Human Migration in Island Southeast Asia. Oxford: Blackwell-Wiley.

Boeg Thomsen, Ditte and Jan Heegård eds. 2018. Spatial language, cognition and environment. Special issue of Acta Linguistica Hafniensia. International Journal of Linguistics 50(2).

Bollée, Annegret. 2015. « Le Dictionnaire étymologique des créoles français d'Amérique (DECA) et le « langage des îles > ». Études Créoles 33(1): 65-91. 
Breton, Raymond. 1665. Dictionaire caraïbe françois. Auxerre: Gilles Bouquet [Reprint 1999: Marina Paisa Besada et al. eds.. Dictionnaire caraïbe francais. Révérend Père Raymond Breton. 1665. Nouvelle édition. Paris: Karthala, IRD]

Burenhult, Niclas ed. 2008. "Language and landscape: geographical ontology in cross-linguistic perspective." Language Sciences 30(2-3): 135-382.

Busser, Rik De and Randy J. LaPolla eds. 2015. Language Structure and Environment: Social, cultural, and natural factors. Amsterdam: Benjamins

Bøegh, Kristoffer Friis. 2018. "Spor fra dansk i De amerikanske Jomfruøers engelsk-kreolsk." Mål og Mæle $39(2): 24-29$.

Caldeira, Arlindo Manuel. 2009. “Organising freedom: De Facto Independence on the Island of Annobón during the Eighteenth and Nineteenth Centuries." Afro-Hispanic Review 28(2): 293-310

Carrington, Lawrence D. 1984. St. Lucian Creole. A descriptive analysis of its phonology and morpho-syntax. Hamburg: Buske.

Catford, John C. 1977. "Mountain of tongues: the languages of the Caucasus." Annual Review of Anthropology 6(1): 283-314.

Chaudenson, Robert. 1974. Le lexique du parler créole de la Réunion. Vol. 1. Paris: Honoré Champion. Crowley, Terry. 2013. New Bislama Dictionary. Suva: Institute for Pacific Studies.

Dahl, Östen. 2005. "Att sätta älvdalskan på kartan." In Rapport från \{Fuost\} konferensn um övdalsku (\{Första\} konferensen om älvdalska), edited by Gunnar Nyström. Uppsala: Institutionen för nordiska språk, Uppsala universitet.

Eberhard, David M., Gary F. Simons and Charles D. Fennig. 2019. Ethnologue: Languages of the World, twenty-second edition. Dallas, Texas: SIL International. http://www.ethnologue.com

Everett, Caleb. 2013. "Evidence for direct geographic influences on linguistic sounds: The case of ejectives." PLOS ONE 8(6): e65275. https://doi.org/10.1371/journal.pone.0065275

Everett, Caleb. 2017. "Languages in drier climates use fewer vowels." Frontiers in Psychology 8: 1285. doi 10.3389/fpsyg.2017.01285

Everett, Caleb, Damián E. Blasi and Seán G. Roberts 2015. “Climate, vocal folds, and tonal languages: connecting the physiological and geographic dots." Proceedings of the National Academy of Sciences of the United States of America 112: 1322-1327.

Everett, Caleb, Damián E. Blasi and Seán G. Roberts 2016. "Language evolution and climate: the case of desiccation and tone." Journal of Language Evolution 1: 33-46.

Fattier, Dominique. 2013. "Haitian Creole structure dataset." In: Atlas of Pidgin and Creole Language Structures Online, edited by Susanne M. Michaelis, Philippe Maurer, Martin Haspelmath, and Magnus 
Huber. Leipzig: Max Planck Institute for Evolutionary Anthropology.

http://apics-online.info/contributions/49, last accessed on October 28, 2018

Fortescue, Michael. 1988. Eskimo orientation systems. Copenhagen: Museum Tusculanum Press

(Meddelelser om Grønland, 261 and Man and Society, 11)

Fortescue, Michael. 2011. Orientation Systems of the North Pacific Rim. Copenhagen: Museum Tusculanum Press.

Fortescue, Michael. 2018. "Icelandic, Faroese and Greenlandic orientation systems: all absolute?" Acta Linguistica Hafniensia 50(2): 161-179.

François, Alexandre. 2004. "Reconstructing the geocentric system of Proto-Oceanic." Oceanic Linguistics 43(1): 1-31. doi: 10.1353/ol.2004.0009

François, Alexandre, Michael Franjieh, Sébastien Lacrampe, and Stefan Schnell. 2015. "The exceptional linguistic density of Vanuatu: Introduction to the volume." In The Languages of Vanuatu: Unity and Diversity, edited by Alexandre François, Sébastien Lacrampe, Michael Franjieh and Stefan Schnell, 1-21. Canberra: Asia-Pacific Linguistics (Studies in the Languages of Island Melanesia, 5).

https://openresearch-repository.anu.edu.au/handle/1885/14819. Last accessed on February 17, 2020. Friðriksson, Finnur. 2008. Language change vs. stability in conservative language communities: A case study of Icelandic. Gothenburg: University of Gothenburg. (Gothenburg Monographs in Linguistics, 37). Frowein, Friedel Martin. 2015. "Walk around the clock. The shaping of a (counter-)clockwise distinction in Siar directional." In Language structure and environment: Social, cultural, and natural factors, edited by Rik De Busser and Randy J LaPolla, 227-260. Amsterdam: Benjamins.

Gavin, Michael C. and Nokuthaba Sibanda. 2012. "The island biogeography of languages." Global Ecology and Biogeography 21(10): 958-967.

Glottolog. See Hammarström et al.

Guđmundsson, Helgi. 1977. “Um ytri ađstæđur íslenzkrar málpróunar.” In Sjötíu ritgerđir helgađar Jakobi Benediktssyni 20. júlí 1977, edited by Einar G. Pétursson and Jónas Kristjánsson, 314-325. Reykjavík: Stofnun Árna Magnússonar.

Hall, Neville T. 1992. Slave Society in the Danish West Indies: St. Thomas, St. John and St. Croix. Mona, Jamaica: University of the West Indies Press.

Hall, Robert A., Jr. 1953. Haitian Creole: Grammar - texts - vocabulary. Baltimore: Waverly Press. Hammarström, Harald, Robert Forkel, and Martin Haspelmath. 2018. Glottolog 3.3. Jena: Max Planck Institute for the Science of Human History. http://glottolog.org, latest access on October 31, 2018 Hancock, Ian F. 1987. "A preliminary classification of the anglophone Atlantic creoles with syntactic data from thirty-three representative dialects." In Pidgin and Creole languages. Essays in memory of John E. Reinecke, edited by Glenn G. Gilbert, 264-333. Honolulu: University of Hawaii Press. 
Harmsen, Jolien, Guy Ellis, and Robert Devaux. 2014. A History of St Lucia. Vieux Fort: Lighthouse Road Haurholm-Larsen, Steffen. 2016. A Grammar of Garifuna. PhD Dissertation, University of Berne.

Heine, Bernd. 1997. Cognitive foundations of grammar. Oxford: Oxford University Press.

Highfield, Arnold. 2018. The Cultural History of the American Virgin Islands and the Danish West Indies: A Companion Guide. Christiansted, United States Virgin Islands: Antilles Press.

Hjorth, Birte. 1980. Degnene i Hollænderbyen - om skolen, kirken og de gejstlige indtil 1812. Copenhagen:

Lokalarkivet i Dragør-Store Magleby.

Hoff, Berend. 1994. "Island Carib, an Arawakan language which incorporated a lexical register of Carib origin, used to address men". In Mixed Languages. 15 Case Studies in Language Intertwining, edited by Peter Bakker and Maarten Mous, 161-168. Amsterdam: IFOTT

Holm, John and Peter L. Patrick. 2007. Comparative Creole Syntax. London: Battlebridge. (Westminster

Creolistics Series, 7)

Hymes, Dell ed. 1971. Pidginization and Creolization of Languages. Cambridge: Cambridge University Press. Jackson, Tatjana. 1998. “On the Old Norse System of Spatial Orientation”. Saga-Book 25: 72-82.

Jansen, Silke. 2012. “Les éléments amérindiens dans le 'langage des îles' d’après le Dictionnaire caraïbefrançois (1665) de Raymond Breton." In Americana Romana in colloquio Berolinensi: Beiträge zur transversalen Sektion II des XXXII. Romanistentages (25.-28.09.2011), edited by Christine Felbeck, Claudia Hammerschmidt, Andre Klump and Johannes Kramer, 77-112. Frankfurt a.M.: Peter Lang. Johanson, Lars and Martine Robbeets eds. 2010. Transeurasian verbal morphology in a comparative perspective: genealogy, contact, chance. Wiesbaden: Harrassowitz. (Turcologica 78.)

Karlsson, Bjarki M., Halldóra Kristinsdóttir, Jón Símon Markússon, Kristín Lena Porvaldsdóttir, Kristján Árnason og Sigrún Gunnarsdóttir. 2012. “Um hljóđkerfislegan breytileika í færeysku: lítil forrannsókn.” In: Frændafundur 7: Fyrirlestrar frá íslensk-færeyskri ráđstefnu í Reykjavík 21.-22. ágúst 2010, edited by Magnús Snædal og Turið Sigurđardóttir, 73-90. Reykjavík: Hugvísindastofnun.

Kloss, Heinz. 1967. "'Abstand languages' and 'Ausbau languages'", Anthropological Linguistics 9(7): $29-41$. Knight, Hardwicke. 1964. "Preface." in Preliminary Report 1. Papers of Hardwicke Knight, Hocken Library, University of Otago, MS-4118-107.

Ladhams, John. 2009. “The Formation of the Portuguese-based Creoles: Gradual or abrupt?" In Gradual Creolization, edited by Rachel Selbach et al., 279-303. Amsterdam: Benjamins.

Le Dû, Jean and Guylaine Brun-Trigaud. 2011/2013. Atlas linguistique des Petites Antilles. 2 Vols. Paris: Comité des travaux historiques et scientifiques - CTHS.

Levinson, Stephen. 2003. Space in Language and Cognition. Cambridge: Cambridge University Press. Liddell, Henry George and Robert Scott. 1940. A Greek-English Lexicon. Oxford: Clarendon Press. [1843] 
Lupyan, Gary and Rick Dale. 2010. "Language structure is partly determined by social structure." PLoS ONE 5(1), e8559: e8559. https://doi.org/10.1371/journal.pone.0008559

Lynch, John and Terry Crowley. 2001. Languages of Vanuatu: A new survey and bibliography. Canberra:

Australian National University. (Pacific Linguistics, 517)

Marck, Jeffrey C. 1986. "Micronesian dialects and the overnight voyage." Journal of the Polynesian Society 95(2): 253-258.

Markússon, Jón Símon. 2017. “Samband veiklunar og hljóđanvæđingar: Vitnisburđur u-hljóđvarpvíxla í frum- og vesturnorrænni málsögu." In Bók Jógvan, edited by Zakaris Svabo Hansen, Anfinnur Johansen,

Hjalmar P. Petersen and Lena Reinert, 263-276. Tórshavn: Føroya fróđskaparfelag

Maxwell-Stuart, Hamish. 2010. "Convict transportation from Britain and Ireland, 1615-1870." History Compass 8(11): 1221-1242.

McConvell, Patrick. 1996. "Backtracking to Babel: the chronology of Pama-Nyungan expansion in Australia." Archaeology in Oceania 31(3): 125-144.

McWhorter, John C. 2007. Language Interrupted: Signs of Non-Native Acquisition in Standard Language.

Oxford: Oxford University Press.

Mead, Margaret. 1956. New Lives for Old Cultural Transformation - Manus, 1928-1953. New York:

William Morrow.

Michaelis, Susanne, Philippe Maurer, Martin Haspelmath and Magnus Huber, eds. 2013. The Atlas of Pidgin and Creole Structures Online. Leipzig: Max Planck Institute for Evolutionary Anthropology.

Mitchinson, John. 2012. Danish in the Faroe Islands: A Post-Colonial Perspective. Doctoral thesis, London:

University College London. https://discovery.ucl.ac.uk/id/eprint/1348494/

Monteil, Christian. 2010. « Le créole encore très largement majoritaire à La Réunion. » Revue Économique de l'INSEE, 137. https://www.insee.fr/fr/statistiques/fichier/1292364/revue137-creole.pdf Mühlhäusler, Peter. 1998. "Some Pacific Island Utopias and their Languages." Plurilinguismes 15: 27-47. Mühlhäusler, Peter and Elaine Stratford. 1999. "Speaking of Norfolk Island: From dystopia to utopia?” In Small Worlds, Global Lives: Islands and Migration, edited by Russel King and John Connel, 213-234. London: Pinter.

Muturzikiña (C) 2019. Hizkuntza isolatuak \& sailkatu gabe. http://www.muturzikin.com/carteisolat.htm. Last accessed February 19, 2020.

Nash, Joshua. 2015. "Island placenaming and insular toponymies." Names 63(3): 146-157.

Nash, Joshua. 2016. "Creole spatiality and Pitcairn Island: a comment on Feinberg and Mawyer's Ethos." Ethos 44(1): 3-8.

Nash, Joshua. 2017. "Linguistics, geography, and the potential of Australian island toponymies." Australian Geographer 48(4): 519-537. 
Nichols, Johanna 1992. Linguistic Diversity in Space and Time. Chicago and London: The University of Chicago Press.

Ozanne-Rivierre, Françoise. 1997. "Spatial reference in New Caledonian languages". In Referring to space: studies in Austronesian and Papuan languages, edited by Gunter Senft, 83-100. Oxford: Oxford University Press

Palmer, Bill. 2002. "Absolute spatial reference and the grammaticalisation of perceptually salient phenomena." In Representing Space in Oceania: Culture in Language and Mind, edited by Giovanni Bennardo, 107-157. Canberra: Pacific Linguistics.

Palmer, Bill. 2007. "Pointing at the lagoon: directional terms in Oceanic atoll-based languages." In Language description, history and development: linguistic indulgence in memory of Terry Crowley, edited by Jeff Siegel, John D. Lynch and Diana Eades, 101-118. Amsterdam: Benjamins.

Palmer, Bill. 2009. Kokota grammar. Canberra: Oceanic Linguistics Special Publications.

Palmer, Bill. 2015. "Topography in language: Absolute frame of reference and the Topographic Correspondence Hypothesis." In Language structure and environment: Social, cultural, and natural factors, edited by Rik De Busser and Randy J LaPolla, 179-226. Amsterdam: Benjamins.

Palmer, Bill, Jonathon Lum, Jonathan Schlossberg and Alice Gaby. 2017. "How does the environment shape spatial language? Evidence for sociotopography." Linguistic Typology 21(3): 457-491. https://doi.org/10.1515/lingty-2017-0011

Pálsson, Hermann. 1996. Keltar á Ísland. Reykjavik: Háskólaútgáfan.

Pericliev, Vladimir. 2005. "There is no correlation between the size of a community speaking a language and the size of the phonological inventory of that language." Linguistic Typology 8(3): 376-383. DOI: https://doi.org/10.1515/lity.2004.8.3.376.

Prescod, Paula. 2004. A Grammatical Description of the Noun Phrase in the English-Lexified Creole of St Vincent and the Grenadines. Ph.D. dissertation, Université Paris III - Sorbonne Nouvelle.

Prescod, Paula. 2015. Language issues in Saint Vincent and the Grenadines. Amsterdam: Benjamins. Prescod, Paula and Adrian Fraser. 2008. "A Demolinguistic Profile of St. Vincent and the Grenadines or a Successful Attempt at Linguistic Disenfranchisement." Anthropos 103(1): 99-112.

Quesada, J. Diego. 2017. Gramática de la lengua garífuna. Hermosillo, Sonora: Universidad de Sonora. Rajemisa-Raolison, Régis. 1966. Grammaire malgache. Fianarantsoa: Librairie Ambozontany.

Reinecke, John E., Stanley M. Tsuzaki, Ian F. Hancock and Richard E. Wood, eds. 1975. A Bibliography of Pidgin and Creole Languages. Honolulu: University Press of Hawaii.

Robbe, Joost. 2019. Hvordan en gammel kontrakt kan kaste nyt lys over hollændernes skriftsprog på Amager i 1600-tallet. In The Sign of the V-Papers in Honour of Sten Vikner, edited by Ken Ramshøj 
Christensen, Henrik Jørgensen and Johanna L. Wood (eds.), 503-521. Aarhus: AU Library Scholarly Publishing Services DOI: 10.7146/aul.348.113.

Roberts, Séan and John Winters. 2013. "Linguistic diversity and traffic accidents: Lessons from statistical studies of cultural traits." PLOS ONE 8(8): e70902. doi:10.1371/journal.pone.0070902

Ronström, Owe. 2009. 'Island words, Island worlds: The origins and meanings of words for 'Islands' in North-West Europe." Island Studies Journal 4(2): 163-182.

Rose, Françoise. 2015. “On male and female speech and more: categorical gender indexicality in indigenous South American languages." International Journal of American Linguistics 81 (4): 495-537.

Rouse, Robert. 2016. "Dynamic fluidity and wet ontology: Current work on the archipelagic North Sea." Postmedieval: A Journal of Medieval Cultural Studies 7: 572-580.

Sabino, Robin. 2012. Giving Jack his Jacket - Language Contact in the Danish West Indies. Leiden: Brill. Schreier, Daniel. 2003. "Insularity and Linguistic Endemicity." Journal of English Linguistics 31(3): 249-272. Schreier, Daniel, Peter Trudgill, Edgar W. Schneider and Jeffrey P. Williams eds. 2010. The Lesser-Known Varieties of English. Cambridge: Cambridge University Press.

Sebba, Mark. 1997. Contact Languages: Pidgins and Creoles. London: Macmillan Press

Senft, Gunter ed. 1997. Referring to space: studies in Austronesian and Papuan languages. Oxford: Oxford University Press.

St-Hilaire, Aonghas. 2011. Kweyol in postcolonial Saint Lucia globalization, language planning, and national development. Amsterdam: Benjamins. (Creole language library, 40.)

Staudacher-Valliamée, Gillette. 1992. Phonologie du créole réunionnais: unité et diversité. Paris: Peters. Staudacher-Valliamée, Gillette. 2004. Grammaire du créole réunionnais. Paris: SEDES.

Steinhauer, Hein 1991. "Demonstratives in the Blagar language of Dolap (Pura, Alor, Indonesia)." In Papers in Papuan linguistics, edited by Tom Dutton, 177-221. Canberra: Pacific Linguistics.

Steinhauer, Hein. 1995. "Two varieties of the Blagar language (Alor, Indonesia)." In Tales from a concave world: Liber amicorum Bert Voorhoeve, edited by Connie Baak, Mary Bakker and Dick van der Meij, 269296. Leiden: Projects Division, Department of Languages, Cultures of South-East Asia \& Oceania.

Steinhauer, Hein. 2010. "Pura when we were younger than today." In Studia antropologica. A Festschrift in honour of Michael Chlenov, edited by Artem Fedorchuk and Svetlana Chlenova, 261-283. Jerusalem: Mosty Kul'tury Gesharim.

Steinhauer, Hein. 2014. "Blagar". In Papuan Languages of Timor, Alor and Pantar: Sketch Grammars, Vol. 1, edited by Antoinette Schapper, 148-218. Berlin: Mouton de Gruyter.

Sylvain, Suzanne. 1979. Le créole haïtien. Morphologie et syntaxe. Genève: Slatkine Reprints. [1936]

Taylor, Douglas R. 1971. "Grammatical and lexical affinities of creoles." In Pidginization and Creolization of Languages, edited by Dell Hymes, 293-296. Cambridge: Cambridge University Press. 
Thráinsson, Höskuldur, Hjalmar P. Petersen, Jógvan í Lón Jacobsen and Zakaris Svabo Hansen. 2004.

Faroese: An Overview and Reference Grammar. Torshavn: Føroya Fróðskaparfelag

Thurah, Laurits de. 1758. Omstændelig og tilforladelig Beskrivelse over den liden Øe Amager og den ei langt derfra situerede endnu mindre Øe Saltholm. København: Nicolaus Møller.

Trudgill, Peter. 1974. "Linguistic change and diffusion: description and explanation in sociolinguistic dialect geography." Language in Society 3: 215-246.

Trudgill, Peter. 2004. "Linguistic and social typology: The Austronesian migrations and phoneme inventories." Linguistic Typology 8(3): 305-320. DOI: https://doi.org/10.1515/lity.2004.8.3.305.

Van Rossem, Cefas. 2017. The Virgin Islands Dutch Creole Textual Heritage: Philological Perspectives on Authenticity and Audience Design. Utrecht: LOT.

Veth, Peter. 2000. "Origins of the Western Desert language: convergence in linguistic and archaeological space and time models." Archaeology in Oceania, 35(1): 11-19.

Wassmann, Jürg and Pierre R. Dasen. 1998. "Balinese spatial orientation: Some empirical evidence of moderate linguistic relativity." Journal of the Royal Anthropological Institute 4(4): 689-711. DOI: $10.2307 / 3034828$

Wellfelt, Emilie. 2016. Historyscapes in Alor. Approaching Indigenous Histories in Eastern Indonesia. PhD dissertation, Växjö: Linnaeus University, Sweden.

Weyhe, Eivind. 2014. Variatión av i og u í herđingarveikari støðu í føroyskum. Fróđskaparrit 61: 116-138.

Willemsen, Jeroen. 2020 (in print). "Reta." In Papuan Languages of Timor, Alor and Pantar: Sketch Grammars, Vol. 3, edited by Antoinette Schapper. Berlin: Mouton de Gruyter.

Williams, Jeffrey P., Edgar W. Schneider, Peter Trudgill and Daniel Schreier eds. 2015. Further Studies in the Lesser-Known Varieties of English. Cambridge: Cambridge University Press.

Wulf, Valérie de. 2014a. Histoire de l'île d'Annobon et de ses habitants. Paris: L'Harmattan.

Wulf, Valérie de. 2014b. Les Annobonais, un peuple africain original. Paris: L'Harmattan.

Young, Adrian. 2016. Mutiny's Bounty: Pitcairn Islanders and the Making of a Natural laboratory on the Edge of Britain's Pacific Empire. Ph.D. dissertation, Department of History, Princeton University 